\title{
FROM BARBIE TO RENOIR: INTELLECTUAL PROPERTY AND Culture
}

\author{
Susy Frankel*
}

\begin{abstract}
Barbie has become part of popular culture and this inaugural professorial lecture uses her iconic cultural status to discuss the relationship between culture and intellectual property. Intellectual property is frequently treated in New Zealand as primarily involving economic policy. However, it is also part of cultural policy. In her inaugural lecture, Professor Susy Frankel discusses how the articulation of the relationship between intellectual property and cultural values could lead to an improved intellectual property law for New Zealand, particularly in the fields of copyright and trade marks.
\end{abstract}

\section{THANKS}

This article is a reproduction of my professorial inaugural lecture, delivered on 10 March 2009. The lecture included visual images that cannot be fully reproduced here. ${ }^{1}$ My lecture began with thanks which I wish to record. There are many people to thank for encouraging me along the path towards becoming a professor, but it is not possible to name them all. On the occasion of the lecture I thanked Paul Scott, whose enthusiasm and support for my academic career is unsurpassed. I take the opportunity in writing to add thanks to Professors Rochelle Dreyfuss and Jane Ginsburg, both of New York, for their mentoring; Virginia Grainer, who encouraged me to become an academic; David McLauchlan, John Prebble and Bob Dugan who, in quite different ways, have taught me many things about teaching; and the collegiality, in particular of the women, of the Victoria University Faculty of Law.

* Professor of Law, Victoria University of Wellington.

1 The Vice-Chancellor of the university, Professor Pat Walsh, introduced the lecture and his text is not reproduced here. The lecture is available as a podcast at $<$ www.victoria.ac.nz/home/about/newspubs/ podcasts/inaugural-lecture/susy-frankel.aspx>. 


\section{INTRODUCTION}

It may seem somewhat infra dig to talk of Barbie in an inaugural lecture. She certainly is not highfalutin' and in the eyes of many Barbie lacks gravitas. ${ }^{2}$ She undoubtedly, however, has economic gravity.

Barbie began life as a German doll, known as Bild Lilli, who was based on a cartoon. ${ }^{3}$ Mattel, the international toy company that has created the mass-marketed Barbie product we know today, bought the rights to this doll. As the Ninth Circuit Court of Appeal in the United States noted Mattel transformed her over the years: ${ }^{4}$

She has survived attacks both psychic (from feminists critical of her fictitious figure) and physical (more than 500 professional makeovers). She remains a symbol of American girlhood, a public figure who graces the aisles of toy stores throughout the country and beyond. With Barbie Mattel created not just a toy but a cultural icon.

In addition to illustrating a number of points about intellectual property, which I will shortly discuss, Barbie is now 50 years old and although not new she is a modern icon. ${ }^{5}$

In contrast, Renoir was born in 1841. This was an important time in European art, but from the New Zealand perspective it was shortly after the signing of the Treaty of Waitangi and before British style copyright laws took hold in New Zealand. ${ }^{6}$ Although Renoir is part of the impressionist art era and not the romanticism era, he is an archetype of the romantic view of intellectual property, and particularly copyright. The view to which I refer is that it is designed to protect and encourage individual creativity. Renoir once said "Shall I tell you what I think are the two qualities of a work of art? First, it must be the indescribable, and second, it must be inimitable". ${ }^{7}$ This view that quality

2 In many intellectual property classes I have used examples of Barbie imitations, parodies, critiques and commentary to illustrate the boundaries of trade mark rights, passing off, the Fair Trading Act 1986 and copyright. I thank the many students who have contributed to the discussion of these boundaries. The continuous dialogue with students has enhanced my research.

3 See picture at $<$ http://en.wikipedia.org/wiki/Bild_Lilli_doll $>$.

$4 \quad$ Mattel Inc v MCA Records 296 F 3d 894 (9th Cir 2000) at 898.

5 Coincidentally Barbie's 50th birthday was the day before my inaugural lecture, 9 March 2010.

6 New Zealand has generally adopted British copyright law. New Zealand had enacted British style copyright law in the form of a Copyright Ordinance 1842. Although there was some legislation between then and early in the 20th century United Kingdom law developed and it was not until 1913 that New Zealand law caught up. The New Zealand Copyright Act 1913 was substantively based on the 1911 United Kingdom Act. There have over the years been some minor differences between British and New Zealand copyright law. The major differences emerged in the late 20th and early 21 st centuries. These differences include New Zealand laws to allow parallel importing of copyright goods, see Copyright Act 1994, s 35 and s 12(3) and the introduction of the Copyright (New Technologies) Amendment Act 2008.

7 "Pierre August Renoir quotes" ThinkExist <http://thinkexist.com> 
art could not be imitated is interesting because Renoir seems to suggest the idea that imitation would not create the same indescribability to which he refers. This belief that imitation is inherently inferior was obviously a consequence of the man and the times in which he lived. It is not necessarily a belief that prevails in the world today or even then. That Renoir was not a man who moved with the times is also illustrated by his comment that women should not become lawyers. ${ }^{8}$

More seriously, however, Renoir represents the individual artist, whose creativity, in the minds of those who perpetuate an idealistic view of intellectual property law, requires protection. Renoir thought that he could not be imitated. Whatever he meant by that painters of his generation would be surprised to find out their paintings can be downloaded from the internet and even given a few extra features if need be. Subsequent to Renoir's death his original paintings have sold for millions one reportedly for more than US\$70 million. ${ }^{9}$ So it would seem that Renoir has economic weight also, even long after any intellectual property rights in his work have expired.

This may suggest that copyright is not important for all creative activity. Indeed, certain types of creativity may flourish regardless of the existence of proprietary rights. Even if, however, that is true it does not mean that there should not be copyright protection. At the most it shows that some creativity does not need copyright, but this does not mean that all creativity does not need copyright to prosper. Authors and those who own copyright should be able to economically benefit from their creativity and copyright enables many to do so.

Copyright in some ways is even-handed. It protects high quality and low quality works. It does not require that works have a high degree of creativity for copyright production. Where works are the result of a creation process, no matter how creative or otherwise, and those works meet the qualifications for copyright they will be protected. ${ }^{10}$

\section{INTELLECTUAL PROPERTY RIGHTS}

Barbie is emblematic of products that emanate from so-called cultural and creative industries. Cultural and creative industries have flooded the world with toys, films, music and all kinds of merchandise. Intellectual property rights are enormously important for cultural and creative industries. This importance is evident, for example, on Mattel's website which states: ${ }^{11}$

$8 \quad$ Ibid.

9 Rita Reif "Café Scene by Renoir is sold for \$78.1 Million" The New York Times (United States of America, 18 May 1990).

10 These qualifications are that the work can be categorised as a copyright work and that that is original, see Copyright Act 1994 (NZ) s 14 and the Berne Convention for the Protection of Literary and Artistic Works (24 July 1971) art 2.

11 "Mattel, Inc. Website terms and Conditions" Mattel < http://corporate.mattel.com>. 
In using this Website, you must respect the intellectual property rights of Mattel and others, all as outlined below. Your unauthorized use of Content may violate copyright, trademark, privacy, publicity, communications, and other laws, and any such use may result in your personal liability, including potential criminal liability.

Intellectual property rights are the legal mechanisms used to make sure that no competitor can produce the same products. Intellectual property rights, particularly copyright and trade marks, enable cultural industries to profit from the notion that their products are "genuine" and consequently desirable for consumers to purchase. This is perhaps the modern version on Renoir's concept of unable to be imitated. Many mega-successful product or product lines, such as Barbie, have corporate owners who are vigilant about protecting their intellectual property rights and fight off those who attempt to free ride in any way on them. But not all so-called free rides should be treated the same. Some free rides are valuable to society because great works can be improved by other authors. There are many examples of this. One example which Richard Posner has used to illustrate the difference between copyright infringement and plagiarism is illustrative. The first quoted paragraph comes from Thomas North and the second passage from that well-known plagiarist William Shakespeare. $^{12}$

She disdained to set forward otherwise, but to take her barge in the river of Cydnus; the poope whereof was of gold, the sailes of purple, and the owers [oars] of silver, which kept stroke in rowing after the sounde of the musick of flutes, howboyes, citherns, violls, and such other instruments as they played upon in the barge.
The barge she sat in, like a burnished throne, Burnt on water. The poop was beaten gold; Purple the sails, and so perfumed that The winds were lovesick with them. The oars were silver,

Which to the tune of flutes kept stroke, and made

The water which they beat to follow faster ...

However, improvement is not a prerequisite for use of another's work; commentary, criticism and parody are all important for society and cultural icons are the natural subject of such activity.

No one other than those that Mattel might permit can manufacture a doll called Barbie or even something that looks too similar. How much similarity amounts to too much similarity is the copyright infringement question. ${ }^{13}$ One point is that, many dolls can appear in pink packaging but if it looks too much like a Barbie that might infringe Mattel's rights.

12 Plutarch "Life of Marcus Antonius" (translated by Thomas North) and William Shakespeare "Antony and Cleopatra" in Richard A Posner The Little Book of Plagiarism (Pantheon Books, New York, 2007).

13 What amounts to copyright infringement in New Zealand is governed by the Copyright Act 1994. See ss 2930 relating to infringement by reproduction. Broadly the test for infringing copyright by reproduction is when the whole or a substantial part of a copyright work has been copied. Substantiality is not a quantitative test; rather it is a qualitative test. See also Wham-O Manufacturing Co and Others $v$ Lincoln Industries Ltd [1984] 1 NZLR 641 (CA). 
The Barbie photo cited at the beginning of this lecture is from Wikipedia. ${ }^{14}$ It is very hard to download a Barbie image from Mattel's website, in fact attempts to do so will tell you this image is protected by copyright and may not be used. If the image could be downloaded, doing so might still be an infringement, but Mattel have removed the choice to infringe via download. That is what intellectual property is for. No one else can use the exact image and Mattel's technological limitations on its website are an entirely legitimate way for a copyright owner to protect its works. Whether copyright law needs to, as it does in many jurisdictions the United States of America, European Union, Australia and New Zealand included, protect those technological protection mechanisms under copyright law is another debate and not one I will canvas here.

\section{COPYRIGHT AND THE INTERNET}

The debate over how to protect copyright works on the internet has been and continues to rage. About the only thing everyone is agreed on is that there are far-reaching consequences arising from intellectual property's involvement in the internet world, whatever that involvement is. The reach of copyright affects consumers and whether they can download movies, songs, television programmes from the internet. Once a legitimate download has been completed the question then becomes whether consumers should be able to transfer the copyright works to their iPods or other devices. People use information from the internet all the time and wonder how much they can quote - or if they can quote at all. Many of these questions go unanswered, particularly for the lay person. While it is trite to say the internet has changed our lives. It simply has. But importantly it has changed our culture, our attitudes to culture, and the ways in which cultural products are developed and distributed. What is far from clear is whether the role of intellectual property law in this changed world is operating as it ought to.

There is no shortage of views both within and outside the field of intellectual property law about how to reform intellectual property law to reflect the modern world. These views range from suggestions that intellectual property rights should be abandoned altogether, ${ }^{15}$ to a range of ways in which the rights should be adapted for modern conditions and recognition of their economic importance. ${ }^{16}$ Much of this debate has centred around what use can be made of intellectual property works. What are the limits of personal use or use for educational purposes and so on.

14 Some of the others I used in the lecture were photos that I took.

15 See, for example, the discussion in Jane C Ginsburg "How Copyright Got a Bad Name For Itself" (2002) 26 Columbia Journal of Law and the Arts 1 at 2-3.

16 During the submissions process of the New Zealand Copyright (New Technologies) Amendment Act 2008, several submissions were made that the whole of copyright should be overhauled to deal with the digital era. Written submissions are available on line at "Committee Documents" New Zealand Parliament $<$ www.parliament.nz>. 
Take for example - teaching in a university - can a lecturer make 40 copies of an article and distribute it to students? Under existing law the answer is no. ${ }^{17}$ Students can, however, each make a copy for themselves. ${ }^{18}$ And there are many nuances of this scenario involving libraries and teachers acting as agents for students and so on. In my view the law has lost the plot and become fundamentally flawed when valuable time is wasted on this question - 40 copies are made for education and it should not matter who makes them. The same people end up with the same number of copies and any law that says you have to do this by a time and consuming multi-step process is out of touch with reality and discourages efficiency. That said copyright owners ought to have a return for use of their work.

Intellectual property on the internet is a complex issue. Two broad strands can be pulled from this complexity. Those strands raise different issues. The protection of big brands is different from the protection of big company interests in multiple smaller intellectual property works. The protection of the name "Sony", for example, is different from the protection of the many sound recordings that Sony owns. ${ }^{19}$ But it seems that the public has in some quarters conflated the two. The big brand issue roughly comes down to: "you are big, you are famous and you should not be untouchable". The corporate ownership issue is about big profits in the name of promoting creativity of artists. The objection here is using the Renoir ideal of the individual creator for another purpose. Professor Jane Ginsburg has convincingly reasoned that copyright has since its creation been used in the Anglo-American world to support corporate claims to authorship. ${ }^{20}$ Public perception has, however, become that it is wrong for these companies to claim they support creativity as an authorial pursuit.

The occasional donation to the arts does not fulfil the authorial ideal. The counter-argument is that these companies do produce creative works. They support a certain type of creativity. Allowing these companies to control distribution of their works and to charge for music copied online is justifiable and is an entirely separate issue from whether people should be allowed to use these works to make new works that are different from the copyright work. That is works that are not an exact imitation, but rather a derivative of it. Derivatives can take many forms such as using the work in another context or using part of the work to create a new work. West Side Story is a derivative of Romeo and Juliet. Many derivatives will be an infringement if they take too much of the original work while that the work is protected by copyright.

17 Copyright Act 1994, s 43(4).

18 Ibid, $\mathrm{s} 43$.

19 The name "Sony" is protected as a trade mark. Each sound recording is a copyright work, see Copyright Act 1994, s 14(1)(b).

20 See for example Ginsburg, above n 15. 
The structure of copyright law is that all copying is an infringement. ${ }^{21}$ In the face of digital technologies law reform has introduced the exception that transient copying that occurs in order to make the internet work should not be an infringement. ${ }^{22}$ The real challenge for copyright is how to adapt a model that is based on all copies being an infringement to the reality that many copies which are made are either not worth suing over or perhaps should not be infringements - because even though they are literally imitations - they do not necessarily result in imitations that compete with the copyright work or imitations in the sense that Renoir may have had in mind. They might be derivatives of works that do not impinge on the market for the original works market and audience, but rather create their own market and audience.

\section{THE REMIX AND PARODY}

Derivative works in the online world are often called remixes. They remix other works. Commentators and bloggers have suggested that any kind of online digital remixing should not be subject to copyright law. One commentator, Lawrence Lessig, has taken this position claiming that remix is so creative we risk stifling creativity unless we allow it. ${ }^{23}$ In his lectures he uses a remix of Bush and Blair to illustrate his point. In this remix various news clips featuring Bush and Blair are mixed so that they appear to be singing the duet "Endless Love" by Lionel Ritchie. ${ }^{24}$ This may in fact be a bad example for Lessig's case because its value is in the parody and is arguably permissible under United States law on that basis. ${ }^{25}$ However, his point is that this is very creative and a valuable form of social comment and creativity which copyright law potentially stifles taking place. To illustrate the difficulty further I look at some more parody and its uses.

One example of an unsuccessful lawsuit brought by Mattel was to prevent the band, known as Aqua, from utilising the name "Barbie" and the images associated with that name in a pop-song and accompanying video that had a twist of parody as well as a catchy tune. ${ }^{26}$ Mattel's complaint was the commercial use that was being made. But Judge Kozinski took the view, essentially, that this was a legitimate parody and told the parties to "chill". ${ }^{27}$ The United States court did not treat this kind of parody, which has a direct commercial value differently from parody without such

21 Copyright Act 1994, s 16.

22 Copyright (New Technologies) Amendment Act 2008, s 43A.

23 See generally Lawrence Lessig Remix: Making Art and Commerce Thrive in the Hybrid Economy (Penguin, New York, 2008).

24 Johan Soderberg "Bush and Blair Love Song" <www.soderberg.tv>.

25 A parody may be considered a fair use in the United States, see 17 USC. $\S 107$. See also Campbell v AcuffRose Music 510 US 569 (1994).

26 Mattel Inc v MCA Records Inc, above n 4.

27 Ibid, at 908 . 
commercial value. It is not clear that all courts, particularly a New Zealand court, would reach this conclusion. Under the current state of New Zealand's law the commerciality might tip a parody into the infringement basket. ${ }^{28}$ There has been no case along those lines in New Zealand. No firm conclusions should, however, be drawn from that because it might mean that no one has been prepared to argue such a case here where there is no clear protection for parody in copyright law. New Zealand is poised to have a debate over the scope of parody. In the New Zealand cultural context what is legitimate parody and what is not?

\section{PARODY AND CULTURE}

Parody is undoubtedly a cultural construct. One person's parody is another person's insult. Does that matter? Is there any New Zealand norm for parody? The nature of parody requires a subject. Some subjects may be viewed by some as inappropriate for parody. In such a situation the cultural value of parody finds itself in competition with another cultural value. One example of such a cultural value is the appropriate use of the knowledge and taonga of Māori.

There are a number of examples of parodies using the well-known haka; ${ }^{29} \mathrm{Ka}$ mate, Ka mate. ${ }^{30}$ One parody has the All Blacks rugby team, singing the haka in high squeaky voices. ${ }^{31}$ It is usually performed in an aggressive macho manner. That may well be a legitimate parody of the All Blacks, but is it an unacceptable parody of Ngāti Toa's haka. ${ }^{32}$ Whether one or the other, or both, should be encouraged or discouraged is a matter of cultural values. The answer lies in where a society is prepared to draw a line to reflect a range of cultural interests. If the most important value is that the intellectual property rights, in the broadcast, should not be infringed the consequence might be that some parodies will not be made. If the most important thing is that free speech determines parody should be permitted, so be it. If the most important thing is that the haka should not be subject to

28 There is no statutory permitted act for parody in New Zealand, only a permitted act for the purpose of criticism or review, Copyright Act 1994, s 42.

29 Haka is a general term that is applicable to many and varied dances, see T Kāretu Haka: The Dance of A Noble People (National Library of New Zealand, Auckland, 1993)

30 "Ka mate Ka mate" are words from the haka that the Crown has acknowledged is the heritage of Ngāti Toa. The relevant settlement between Ngāti Toa and the Crown reported that it would "record the authorship and significance of the haka" to Ngāti Toa. This allows Ngāti Toa to "address their concerns with the haka". The Crown said it did not expect Ngāti Toa to receive royalties or a veto on the performance of the haka. "Ngāti Toa's primary objective is to prevent the misappropriation and culturally inappropriate use of the Ka Mate haka", see Sally Kidson "Big benefits expected from treaty settlement" The Nelson Mail (New Zealand, 11 February 2009). This haka is used extensively by New Zealand's representative rugby team the All Blacks.

31 See "New Zealand Rugby Haka Parody" YouTube <www.youtube.com>.

32 See Susy Frankel and Megan Richardson "Cultural Property and 'the Public Domain': Case Studies from New Zealand and Australia" in Christoph Antons (ed) Traditional Knowledge, Traditional Cultural Expressions and Intellectual Property Law in the Asia-Pacific Region (Wolters Kluwer, The Netherlands, $2009)$ at $280-283$. 
parody of this kind then that value triumphs. I am not going to draw that line here or elevate one of those values but I want to underscore how it is cultural values that are at play in the analysis. And the resolution of this question depends on the weight that a country's lawmakers attribute to those competing cultural values.

\section{CULTURE DRIVING INTELLECTUAL PROPERTY OR INTELLECTUAL PROPERTY DRIVING CULTURE}

The parameters of intellectual property law are essentially a cultural construct. The lawmakers choose which cultural values to protect and to balance them. When intellectual property law is seen as a problem for culture, rather than supportive of it - then the law has a credibility problem.

The basic thesis that if we overprotect intellectual property we run the risk of stifling creativity, underscores the balancing act. This balancing act is not new to intellectual property. The first and most obvious problem with the argument that we should allow all remixing is that already some of it is permitted - lines have already been drawn. ${ }^{33}$ But the real difficulty is that much remixing takes place that might be a copyright infringement and sometimes the copyright owner might object and sometimes the copyright owner does not mind. Uncertainty of this nature can have a chilling effect on creativity. Some would say that is the nature of copyright. In today's world that nature is questioned because the one size fits all approach does not seem to fit all.

Barbie and what she may or may not represent has been and continues to be the subject of sociological and psychological study, of praise, the subject of criticism and the subject of parody. She may even be the inspiration for further creativity. The Aqua song is one example of this derivative creativity. There are many others available online.

To my mind to allow remixing or not is not the real question. The real question is: is it worth it for society? Will culture prosper if we allow unfettered remix? Will authors and owners of copyright works miss out on what they are entitled to? There is a risk in asking these questions that we return to the traditional justifications for intellectual property and those justifications will get us nowhere.

The traditional rationale is that copyright law provides an incentive for the creation of copyright works. Copyright functions as a reward to make sure that people want to produce creative copyright works. Such a rationale is frequently asserted and virtually impossible to prove. It has resulted in questions which ask how much reward is needed: "50 years or 70 years protection?" 34 Copyright

33 Permitted acts are already established in the law, see in New Zealand the Copyright Act 1994.

34 The term for copyright protection in New Zealand, which is the international standard required under the World Trade Organization's intellectual property agreement, known as the TRIPS Agreement, is life of the author plus 50 years, or 50 years from the making where life is not the basis of calculating term, Copyright Act 1994, ss 22-25. In the United States, the European Union and Australia 70 years rather than 50 years is the term of protection, although the exact rules vary in detail between the jurisdictions. 
has generally avoided concluding that some works need more protection and some less. Intellectual property law, and particularly copyright law, purports to have a neutral stance on artistic quality or literary quality or indeed about cultural value at all. ${ }^{35}$ A Samuel Beckett novel is treated the same as the novel you have written part of at home and hidden away. ${ }^{36}$ In copyright the same term of protection is given to works whether they are masterpieces or whether they are a doodle. But works that have come to have huge commercial value have driven the boundaries of the law outwards creating more and more protection. Copyright term has been extended as some commercially valuable products of cultural industries have come towards the end of their protected time. The law that extended copyright term in the United States is officially the Sonny Bono Copyright Term Extension Act. It came into force just as copyright in the first Mickey Mouse film was about to expire, so it is often called the Mickey Mouse term extension act. ${ }^{37}$

The big cultural industry players want a lot more protection than just to stop copies. They have long since worked out that people ignore the copying prohibition and so they have fought and in many places won the battle to achieve exclusive rights to control the methods of copying. In the 70s this meant trying to own the film companies as well as the companies that make the video players. Sony was engaged in a contest with its BetaMax video against VHS. Sony lost to VHS because it did not own any content just the video technology. It was at this point that Sony seems to have worked out it needed to own content. More recently what is important is controlling online markets by protecting the technology that delivers those online markets.

Should copyright owners be able to stop people not paying for copies of music? It is a reasonable argument to say "yes", but it is a different argument to say that copyright owners should be able to legally object to all uses of that music and it is this area of dispute that is harder to solve. It is in this area that copyright owners need to learn to tolerate derivative or what we might call spinoff uses. These uses should be tolerated because these spin-off uses are for a cultural value that might be equally as important as the copyright and furthermore sometimes the second version is superior to the first.

Today music, film and software companies are concerned about what new technology might do to their businesses. While intellectual property owners might have valid concerns hindsight shows that their concerns might sometimes have been overstated. In the late 1970s and early 1980s movie videos became common. The Hollywood studios at that time were horrified at the idea of video and what it might do to their business. Jack Valenti, the then head of the Motion Picture Association of America testified before Congress that the film studios welcomed the introduction of video

35 Artistic works, for example, are protected regardless of artistic quality, see Copyright Act 1994, s 2.

36 In some jurisdictions there are different rules for published and unpublished works. In New Zealand the protection is in most respects the same whether a work is published or unpublished.

37 Sonny Bono Copyright Term Extension Act 112 Stat 2827 (1998). 
recorders as much as women welcomed the Boston strangler. He claimed that video would cause the film studios to haemorrhage. ${ }^{38} \mathrm{He}$ was totally wrong. Within 5 years of his testimony film studios made more money from video than they did from feature films. This was not because fewer people attended feature films. Quite the reverse was true. More people attended films and more people bought videos. Interestingly, there was one film figure who applauded video production. That prophetic figure, who played Moses, was Charlton Heston.

The primary rationale for trade mark protection, such as protection for the Barbie name, is economic. It is about identifying the origin of goods, to reduce consumer search costs and to ensure quality of products. ${ }^{39}$ Trade mark policy is, however, a form of cultural policy, but cultural policy is rarely identified as the primary concern of trade marks.

Barbie, as an example, is much more than a product for purchase. Barbie, Mickey Mouse and many others are not just names of products, they have become part of the modern landscape of where we live and what we do. Barbie has become part of our culture and part of our language. Various Barbies are marketed as representing a range of lifestyles to suit the consumers' lifestyle: Beach Barbie, Office Barbie, Dr Barbie and so on, or even the consumer's race or ethnicity. Even though Barbie's core persona is Caucasian and blonde, she is available in African- American, Hispanic and a variety of other races. The emersion of such products in our culture is not just about the product it is about the image and even the name.

She is intergenerational. If you did not have a Barbie or her former beau, the Ken doll, then chances are your children may have or even their children. But whether you've embraced Barbie or rejected her she is part of our world and even our vocabulary. Someone could be described as Barbie like, this could mean a variety of things. In Barbara Kingsolver's book "Pigs in Heaven" the author wrote: ${ }^{40}$

The waitress rallies quickly. "I'm Barbie. No last name ... I sign it like this with a little trademark sign

after it." She picks up Alice's ballpoint pen and writes a carefully looped, upward slanting BarbieTM.

This language phenomenon is of course particularly prevalent with famous trade marks. We might say that's a Mickey Mouse government or "that's so goofy". But even big trade marks start small and can slowly become part of our language. Because famous trade marks are part of language it is not so unusual for less famous trade marks to end up that way and perhaps even to become famous. It only needs a few people to start asking for a pump bottle before that is the name people

38 Jack Valenti testimony, in Hearings Before the Subcommittee on Courts, Civil Liberties, and the Administration of Justice, House of Representatives, Ninety-seventh congress, Second session (Hr 4783, 4794, 4808, 5250, 5488, 5705, Home recording of copyrighted works, 1982) available at $<$ http://cryptome.org/hrcw-hear.htm $>$.

39 See discussion in Levis Strauss v Kimbyr Investments [1994] 1 NZLR 332 (HC) at 362.

40 Barbara Kingsolver Pigs in Heaven (HarperCollins, New York, 1993) at 139. 
use, rather than buying a bottle of water. Depending on your generation you may ask for a biro rather than a pen. "Biro" is a trade mark, and we are used to using trade marks in language to identify things "please pass me that biro". We Xerox things, we Hoover things - both trade marks. Professor Rochelle Dreyfuss has commented that these well-known marks have become the lingua franca of our world because they are more widely known than signifiers from history, literature or mythology. ${ }^{41}$

Not all of these uses of intellectual property rights, whether they be rights in the name or design and look of the products, would necessarily be infringements of intellectual property rights, but they do show how trade marks and the products of intellectual property are pervasive in our culture.

Another way in which intellectual property is overtly the tool of cultural interest is played out in the World Trade Organization (WTO). Many of the calls against so-called globalisation are calls for the protection of culture. In the GATT ${ }^{42}$ context the "culture" debate has for a long time centred around issues such as how much subsidising can be done of the French film industry before that subsidy distorts trade. ${ }^{43}$ The real battle of cultural interests, however, can be found in the TradeRelated Aspects of Intellectual Property Rights (TRIPS) Council, which is the arm of the WTO that discusses and negotiates agreement on intellectual property issues. ${ }^{44}$ There are two major cultural topics on the agenda. One is the European Union's persistence in increasing what are called geographical indications. Champagne and Roquefort are examples, but the European claim to GIs extends beyond these iconic products. Another so-called geographical indication is a claim of exclusivity to the name 'puy lentils' because they once originated from Le-Puy-en-Valey.

The other major topic before the TRIPS Council is the claims of indigenous peoples and developing countries to the protection of traditional knowledge. ${ }^{45}$ The claims to protect traditional knowledge and to protect geographical indications are both attempts to protect cultural interests. The European Union approach to geographical indications is fundamentally a claim to traditional knowledge dressed up in the language of geographical indications, because that is an accepted language of intellectual property law. Whereas, traditional knowledge does not yet have the status of

41 Rochelle Dreyfuss "Reconciling trademark rights and expressive values: how to stop worrying and learn to love ambiguity" in Graeme Dinwoodie and Mark Janis (eds) Trademark Law and Theory: A Handbook of Contemporary Research (Edward Elgar Publishing, Cheltenham, 2008) at 262.

42 General Agreement on Tariffs and Trade (30 October 1997).

43 See generally Tania Voon Cultural Products and the World Trade Organization (Cambridge University Press, Cambridge (UK) 2007).

44 Under the Agreement on Trade Related Aspects of Intellectual Property Rights, Including Trade in Counterfeit Goods, Annex 1C, Marrakesh Agreement Establishing the World Trade Organization (opened for signature 15 April 1994, entered into force 1 January 1995) [TRIPS Agreement].

45 See TRIPS Council "Article 27.3b, traditional knowledge, biodiversity" (2010) World Trade Organisation $<$ www.wto.org/english/tratop_e/trips_e/trips_e.htm>. 
general acceptability. In both of these instances the economic interests align with the cultural interest. That alignment often occurs in intellectual property law. The difficulties tend to come when the economic interests diverge from some cultural interests.

\section{CONCLUDING THOUGHTS}

Because of the pervasiveness of intellectual property in our culture, the right way to discuss the limits of intellectual property is to understand and try to articulate the relationship between intellectual property and culture. We know it is there but what does this relationship tell us? And how can we use the understanding of that relationship in a practical way?

One of the phenomena that we see is that there have been certain products and brands that have become boom industries. The question that I am interested in is not whether cultural and creative industries are goodies or baddies, whether Barbie has less or more artistic merit than Renoir, but whether if the law over protects these kinds of cultural products we do damage to culture itself. The law is too protective if it starts to be too constricting on the types of artistic, literary and musical works that can be made. The law is too restrictive if people will not create certain works because they are not sure if the law allows them to or not and they cannot easily find out the necessary information to determine if what they do is legal creativity or not.

The problem with the incentive and reward approach to intellectual property is that it loses sight of the public interest in the structure of the law as a whole. In essence the rights of individuals appear to have trumped the collective interests in intellectual property law. Those collective interests include its effect on culture. This includes what we might call expressive values and free speech, but it is not just those values at play. Society has a vested interest in supporting individual rights. The appropriate balance between collective interests and individual rights is not an easy balance to achieve. Finding that balance requires that we look at the fundamental reasons why we have private rights in intellectual property.

Asking how much reward is necessary, and questions of that kind, ultimately do not reveal much more than some businesses do rather well out of intellectual property rights. Looking at the relationship between culture and intellectual property is a much better starting place because ultimately it can show more clearly where to draw the line.

The idea that there is a link between culture and intellectual property is not new. But exactly what the link is, and how it can be appropriately reflected in the law, is not self-evident. The starting clue, that I have used, is that cultural industries are protected by intellectual property rights. But it is not the status as a cultural industry that achieves this. It is the creation of cultural products. You receive copyright whether you are a big player or a small player.

When intellectual property rights interfere too much with the type of cultural product that emerges, particularly from small players, that is when a line can be drawn. But it is complete nonsense to suggest that the drawing of the line is for any reason other than to support one cultural 
interest over another. This dominance of one cultural interest over another is often the consequence of a focus only on economic interests. In as far as New Zealand can, we should draw our own lines about cultural values. Such an approach is also likely to be economically beneficial.

To conclude I am going to indulge in a "remix" of Bob the Builder. Can we draw lines to support New Zealand cultural interests - of course we can.

How to do that and exactly where to draw the line I have hinted at in this lecture. This is the beginning of a lengthy discussion that is too long for now. My research is focussed on how. 